\title{
Standing Commitment of Sale and Purchase Agreement (PPJB) in Purchasing Flats Unit as Legal Protection for Consumers
}

\author{
Ni Putu Teresa Giovana \\ Master Program of Notary Studies Universitas Udayana, Indonesia
}

email: teresagiovana@gmail.com

\begin{abstract}
Research on the commitment of binding sale and purchase (PPJB) in terms of the marketing of flats is a step in legal protection for consumers who will buy flats. This PPJB will bind both parties, namely sellers and buyers for the legal sale and purchase. However, often in terms of the marketing of flats, some rogue developers market flats when the apartment building does not yet have a building permit. This is very contrary to Law Number 20 of 2011 concerning Flats, which says that the marketing of flats must be carried out if the apartment has an IMB. This causes uncertainty of protection for consumers in terms of purchasing flats. Plus PPJB is generally made only with a standard agreement made unilaterally so that consumers cannot freely express their opinions, besides that consumers are also susceptible to losses due to PPJB made without the said IMB. This research was conducted to examine the PPJB in terms of protection for consumers of the flats. This research is normative, namely by way of implementing a legal and conceptual approach. The legal material of this study uses primary legal materials, secondary legal materials and tertiary legal materials by conducting legal material collection using a single method, namely literature study. Protection for consumers is done by using PPJB made by a Notary to minimize the impact that might occur in the future
\end{abstract}

Keywords : PPJB; Flats; Consumer Protection; Buy and Sell; Booking.

\section{INTRODUCTION}

In modern times, human needs are increasing. Primary, secondary, and tertiary needs are very much considered by today's advanced society. People tend to make needs as a form that can be invested. Increasing population growth makes the needs of the home increasingly high. Many middle-income communities choose to own their own homes with property rights so that they can also be used as investment facilities in the future. Houses are a necessity for the community, besides being used as a place to live and can also be used as a savings facility in the old days, namely immovable objects but have a value that is increasingly high. Demand for houses in big cities is increasingly high, and makes a variety of population problems. ${ }^{1}$ Coupled with increased income and the ease of obtaining credit from banks for use in the case of buying a house. This request is not

${ }^{1}$ Dewi, A. A. I. A. A. (2016). Kewenangan Pemerintah dalam Pengendalian Penduduk Pendatang dengan Melibatkan Desa Pakraman. Jurnal Magister Hukum Udayana (Udayana Master Law Journal), Universitas Udayana, 5(4), p. 873. 
commensurate with land in densely populated cities located in the territory of Indonesia. Increasingly interested people and prices that soar every year, resulting in middle-class people rethinking to own a home.

The anxiety is a reference for many companies thinking of making houses vertically (upwards) to minimize existing land but can accommodate many heads of households. Flats are now an option for residents in terms of home ownership but have limited funds to buy houses and land with ownership rights. The flats provide a solution, which can have a flat unit on property or lease rights, but with land that is used as a joint right. More and more days, flats are increasingly in demand by many people, especially people who live in big cities choose to live in flats because they are cheaper and more practical than buying land with property rights and then building a house. ${ }^{2}$ Flats according to Law Number 20 of 2011 concerning the next Flats in this journal are referred to as Flats Laws are multilevel construction units that are established in one area, then consist of several functional parts for residents. The usual house is built vertically (upward) or horizontally (sideways). Ownership of the apartment units is carried out privately but separately, especially the stacking construction is facilitated with shared land, shared objects and shared parts. One alternative is to own a house, but do not use a lot of land (land), the price of which is increasingly increasing, one of which is the construction of flats. Arrangement of cities with flats that are intended for the middle class community can also reduce the construction of slum houses which are increasingly increasing in large cities. ${ }^{3}$

The construction of flats cannot be separated from the many developer companies that are increasingly competing to provide many lucrative facilities for prospective customers to be interested in the apartment units offered. The sale and marketing of these flats is closely related to the licensing issues which have been regulated in the Flats Law. ${ }^{4}$ Construction of flats is closely related to licensing problems that must be done before construction is carried out. In relation to business, companies are always looking for profit gaps in every business. In connection with this, the apartment developer company is marketing, which is related to the licensing problem which is the main spearhead of the construction of flats. ${ }^{5}$

The Housing Law is stated to have regulated things that may or may not be done for the parties. These things are intended for the parties, namely sellers (developer of

${ }^{2}$ Hastuty, R. Y., Winarno, B., \& Istislam. (2015). Perlindungan Hukum terhadap Konsumen dalam Jual Beli Rumah Susun Komersial yang Belum Dibangun. Kumpulan Jurnal Mahasiswa Fakultas Hukum, Universitas Brawijaya, p. 4.

${ }^{3} /$ bid.

${ }^{4}$ Illona, \& Anggraini, A. M. T. (2018). Perlindungan Hukum Konsumen dalam hal Pelaku Usaha Pengembang Rumah Susun yang Sudah Dinyatakan Pailit (Studi terhadap Kemanggisan Residence). Jurnal Hukum Adigama, Universitas Tarumanagara, 1(1), p. 3.

5lbid., p. 2. 
flats) and prospective consumers of apartment units. ${ }^{6}$ The marketing of flats made by the float is closely related to licensing, therefore the marketing of flats has been included in the Flats Law. Problems related to the marketing of these flats, typically associated with flats that have not been built, permits, to agreements made to protect consumers in terms of buying and selling flats. The marketing of these flats is contained in Article 42 of the Flats Law which clearly states the conditions related to the marketing of flats. Generally, problems that arise regarding apartment transactions are a common problem that arises between developers and prospective buyers of apartment units is the problem of flats that are sold using the ordering system. ${ }^{7}$

In the case of an agreement, later it will get an interaction that occurs between the legal subjects, in this case the formulation of the rights and obligations of the parties to be formulated and finally bound to the seller and buyer, and must be carried out by the parties concerned. The occurrence of an agreement if there is an agreement between the two parties making the transaction. ${ }^{8} \mathrm{~A}$ contract is an agreement which in this case is written in writing between two or more people who in this case will create a right and obligation between the parties, and are specifically regulated, subject matter regulated and prohibited for parties to the agreement. ${ }^{9}$ An agreement is basically divided into several types, namely authentic deeds and underhanded deeds.

Authentic deed is an article (agreement) issued by a public official appointed by the Ministry of Law and Human Rights, in which it is written in writing the matter must be carried out or in an event witnessed by the authorized official. Public officials referred to in the making of this authentic deed are notaries, judges, bailiffs in a court, civil registry employees and so on. Authentic deeds have the ability in the case of valid validation for both sides or more along with the descendants of his inheritance accepting the feasibility of the related party.

The Agreement on Binding of Buy and Sell, hereinafter abbreviated as PPJB, is an agreement where the parties bind themselves to each other. ${ }^{10}$ The connection with this journal is that the PPJB Flats is a developer company that ties itself to prospective customers, namely the developer of a flat binds itself by selling the apartment unit and the buyer ties himself to pay a sum of money to the seller. ${ }^{11}$ The function of PPJB for buyers

\footnotetext{
${ }^{6}$ Ramelan, E., et al. (2015). Perlindungan Hukum bagi Konsumen Pembeli Satuan Rumah Susun/Strata Title/ Apartemen. Yogyakarta: Aswaja Pressindo, p. 20.

${ }^{7}$ Adawiyah, P. P., \& Rahman, T. (2017). Analisis Yuridis Putusan PN. Surabaya Nomor: 869/Pdt.G/2013/ PN.SBY (Studi Kasus Ketidakpastian Tenggang Waktu PPJB ke AJB). Novum: Jurnal Hukum, Universitas Negeri Surabaya, 2(2), p.3.

${ }^{8}$ Kusumohamidjojo, B. (2017). Perancangan dan Legalitas Kontrak. Jakarta: CV. Mandar Maju, p. 6.

9/bid., p. 7.

${ }^{10}$ Widjaja, H., \& Tanawijaya, H. (2018). Analisis Perbuatan Melawan Hukum dalam Akta Perjanjian Pengikatan Jual Beli (PPJB) Tanah antara Koko Purnomo Santoso dengan PT. Intan Plaza Adika (Studi Kasus: Putusan Mahkamah Agung Nomor 17/K/Pdt/2016). Jurnal Hukum Adigama, Universitas Tarumanagara, 1(1), p. 3.

${ }^{11}$ Ramelan, E., et al. (2015). Op. Cit., p. 25.
} 
(consumers) is as a guarantee of protection that in the future the apartment units that have been agreed to be purchased are prohibited from selling to different people with the developer, also according to the PPJB the apartment will be handed over to the buyer at a specified time in the PPJB, and will not sing down the advance that the buyer has given to the seller. However, even though there is an agreement that occurs between the two parties, if the object / object of the buying and selling process has not been handed over to the buyer because the buyer has not yet paid off, the ownership rights to the object are still in the seller's hands. stacking.

Based on the explanation of PPJB in terms of consumer protection for flats above, the authors are interested in compiling a journal entitled Position of the Sale and Purchase Agreement (PPJB) in Purchasing Flats as a Legal Protection for Consumers. Based on the background and explanation of the PPJB in terms of consumer protection, the authors draw the formulation of the problem, namely: What is the legal strength of PPJB in the process of buying and selling apartment units? How is the protection for consumers in the purchase of flats made by the order process?

Writing this journal has two objectives, namely general goals and specific objectives. The general purpose is to develop the scientific field of law in the field of notary as a legal study relating to PPJB in terms of consumer protection for flats. The specific purpose of writing this journal is to analyze and understand the strength of PPJB in terms of legal protection for consumers of flats; and to review and analyze the protection of consumers in purchasing flats when buying and selling flats with an order process. The theoretical study related to this research related to this research is later in order to be useful for the reader in connection with the instructions to get references especially in the field of notary and provide additional sources of thought regarding the position of PPJB with regard to legal supervision of buyers regarding sales and home purchases. stacking; for this research lecturer and student team can function as thought material and support lecture activities in terms of PPJB as legal safeguards for clients in the sale and purchase of flats. This research is also expected to be a guide for the community when facing problems in terms of PPJB sale and purchase of flats as legal protection for consumers; for the author, the results of this study can be additional knowledge, especially in the case of PPJB as a legal shield for buyers of apartment sales and purchase transactions and as a final provision for completing final studies in the Notary Masters of the Faculty of Law, Udayana University.

\section{METHOD}

The type of research done in this journal is a normative legal research. This research is based on an ambiguity of the norm related to the position of PPJB in terms of protection against consumers during sale and sale transactions. The Housing Law stipulates that the sale and purchase transactions of flat housing units that are still in 
development stage are made using PPJB manufacture. The process of making PPJB is in front of Notary. The making of PPJB in a sale and purchase transaction of a flat usually uses a basic agreement and is made by the seller, so that the principle of freedom of expression is not practiced at the time of a contract. Other ambiguities that the PPJB did not fully guarantee the buyer in the sale of the flats, because PPJB did not transfer the ownership rights of the flats. The transfer of ownership from the seller to the buyer occurs when the Trade and Purchase (AJB) is signed on behalf of the seller and buyer.

The type of approaches undertaken in this normative legal research isthe statute approach, and the fact approach. This research uses the source of the primary law material namely Civil Code, Law Number 20 Year 2011 About the House, Law Number 8 Year 1999 About Consumer Protection. In addition to primary legal materials, this study also uses secondary sources of legal materials such as legal journals, legal readings, legal papers and journals as well as the opinions of scholars from jurisprudents. Techniques of collecting legal materials conducted in this research are literature study techniques. This research also uses legal analysis technique with description technique, interpretation technique, construction technique, evaluation technique, argumentation technique, and systematization technique.

\section{ANALYSIS AND DISCUSSION}

\section{A. Legal Strengths of the Agreement on Bonds for Sale and Purchase (PPJB) in the Sale and Purchase Process of Flats}

PPJB is an event of sale and purchase of objects in which the parties agree that an item at a future time will transfer ownership rights to another person. This PPJB actually does not result in a transfer of property rights from one party to another, but PPJB is an agreement between sellers who are apartment developers and prospective buyers of flats in terms of buying and selling units of the flats. In addition, PPJB also results in the existence of rights and obligations that must be carried out by both parties. ${ }^{12}$

The emergence of PPJB, wherein the parties are sellers and buyers when linked to the scope of an agreement, PPJB is contained in an obligatory agreement. The definition of an obligatory agreement is one that has been validated so that one agreement will become a bond between the parties, but this agreement only brings out the rights and obligations of the parties bound and has not yet occurred the transfer of rights from the object agreed. ${ }^{13}$ Consideration of the emergence of PPJB in the sale

\footnotetext{
${ }^{12}$ Simamora, N. A., Kamello, T., Sembiring, R., \& Leviza, J. (2015). Asas Itikad Baik dalam Perjanjian Pendahuluan (Voor Overeenkomst) pada Perjanjian Pengikatan Jual Beli Rumah (Studi Putusan Pengadilan Negeri Simalungun No 37/PDT/PLW/2012/SIM). USU Law Journal, Universitas Sumatera Utara, 3(3), p. 88.

${ }^{13}$ Yudhantaka, L. (2017). Keabsahan Kontrak Jual Beli Rumah Susun dengan Sistem Pre Project Selling. Yuridika, Universitas Airlangga, 32(1), p. 88.
} 
and purchase transaction of this flats based on considerations namely; requirements regarding objects that are traded, namely the right to land from the apartment has been legitimately owned by the seller, in this case the developer of flats. Ownership of land rights from this apartment is proven by land certificates or other evidence relating to the land, which is the ownership of the unit development company from Sarusun (flats).

The establishment of a flat unit in the case of licensing is also a collateral for the establishment of an apartment unit, if a marketing of the apartment unit is made early before the establishment of the apartment, then all matters agreed between the developer and the consumer will bound to them as a Sales and Purchase Agreement (PPJB) for these parties. The need for residents to understand the procedures of a business selling and buying apartment units that generally starts from the instruction process (order), then proceed with the PPJB agreement making process if the process of establishing the apartment has reached $20 \%$ (twenty percent) which is the PPJB agreement this was made before a Notary. ${ }^{14}$ PPJB flats are usually made by developers or developers as sellers of the apartment units. The basic engagement that is also carried out by business people in terms of transactions is something that is solely made to facilitate in a trade transaction in this case is the trading of apartment units. An agreement that is made by default will usually facilitate both parties in making an agreement as long as in terms of making the agreement does not harm both parties. ${ }^{15}$ PPJB generally contains matters relating to the rights and obligations of the seller, in this case the developer company and the rights and obligations of consumers of flats. The apartment unit is now not only intended for the upper class community, but also intended for the middle class and also the middle and lower classes, whose apartment units are equipped with adequate facilities in order to create flats as settlements that function for everyone and complete so that Flats become a place to live that is comfortable and safe for its residents. ${ }^{16}$ The Agreement on Bonds for Sale and Purchase (PPJB) if made before a Notary, the strength of the PPJB can be justified, if the making of the PPJB does not conflict with the principles and violates the principle of freedom of contract. The making of this PPJB can be justified even though it is made with a standard agreement or with a collective agreement, provided that the PPJB is not in conflict with the laws and regulations. ${ }^{17}$

\footnotetext{
${ }^{14}$ Nurwulan, P. (2015). Aspek Hukum Transaksi Jual Beli Rumah Susun/Apartemen di Daerah Istimewa Yogyakarta Kaitannya dengan Peran Notaris-PPAT. Jurnal Hukum Ius Quia Iustum, Universitas Islam Indonesia Yogyakarta, 22(4), pp. $674-697$.

${ }^{15}$ Putri, A. D. U. (2010). Tanggung Jawab Developer dalam Perjanjian Pengikatan Jual Beli (Studi pada Apartemen Bellagio the Residence Mega Kuningan). (Magister Tesis), Universitas Diponegoro, Semarang, p. 96.

${ }^{16}$ Triyanto, T., \& Adjie, H. (2018). Perlindungan Hukum terhadap Konsumen atas Perjanjian Pendahuluan dalam Jual Beli atas Satuan Rumah Susun yang Dipasarkan dengan Cara Pre Project Selling. Res Judicata, Universitas Muhammadiyah Pontianak, 1(1), p. 60.

${ }^{17}$ Ibid.
} 


\section{B. Protection for Consumers in Purchasing Flats that Are Made With the Ordering System}

Sale of flats for sale if done in cash or in other words a sale and purchase transaction made by order, is carried out by an agreement which is first carried out through a Sales and Purchase Agreement (PPJB). Generally, the contents of the PPJB regulate the sale and purchase of flats, but the format of the PPJB is generally limited to binding sale and purchase. This means a form of agreement which is a conditional agreement prior to the agreement on the sale of rights for the apartment unit, which after the sale of the purchase from the apartment has been paid, then a deed of transfer of rights is made and the signing of the Sale and Purchase Act

The ordering method in terms of the sale and purchase of flats is a sale and purchase of flats that were carried out before the construction of the flats was completed in terms of development. This is related to the sale of brochures carried out by the developer to consumers and promises that the apartment units received in the future will be the same as those listed in the initial agreement brochure.

Legal protection for consumers is a protection that is intended for weak parties, this is associated with consumer rights in the purchase of flats that are considered weaker compared to the developer of flats. As for the form of protection for consumers, the other part is if the making of a statutory regulation that guarantees the rights and obligations of each party both the seller and the buyer in order to create an orderly society. ${ }^{18}$ Consumers are not just buyers, but consumers are also individuals or business entities that need services and / or goods. The thing that is also useful in the enactment of transactions between buyers and sellers is the switching of objects and / or services, including the transfer of satisfaction in using them. ${ }^{19}$

PPJB is a legal supervision effort for flats consumers if the sale and purchase of flats is used when using the ordering system. This effort is a preventive legal protection effort. ${ }^{20}$ Pelindungan hukum yang timbul sebelum adanya suatu sengketa lazim disebut sebagai preventif. ${ }^{21}$ The PPJB will then contain clauses that must be fulfilled by the parties, and in the PPJB it must be completed with a fine. Normally the sale of apartment units is carried out at an early time before the establishment of the apartment unit is carried out. The sale of the apartment unit purchase is carried out when the apartment has not been built yet, it is carried out with a pre-order method

\footnotetext{
${ }^{18}$ S., Salim H., \& Nurbani, E. S. (2016). Penerapan Teori Hukum pada Penelitian Tesis dan Disertasi. Jakarta: PT. Raja Grafindo Persada, pp. 265 - 270.

${ }^{19}$ Shidarta. (2006). Hukum Perlindungan Konsumen Indonesia. Jakarta: Grasindo, p. 29.

${ }^{20}$ Fitriyani, D. N. (2014). Perlindungan Hukum bagi Pembeli dalam Jual Beli Satuan Rumah Susun dengan Sistem Pemesanan (Studi Kasus Putusan Pengadilan Negeri Jakarta Selatan Nomor 286/Pdt.G/2012/Jkt-Sel). (Magister Tesis), Universitas Gadjah Mada, Yogyakarta, p. 176.

${ }^{21}$ Anggreni, L. D. M. (2016). Pembatalan Perjanjian secara Sepihak oleh Konsumen kepada PT. Bali Dewata Mas sebagai Pengembang Perumahan. (Sarjana Skripsi), Universitas Udayana, Denpasar, p. 5.
} 
of the unit to be purchased by the buyer. After a purchase agreement occurs, the agreement is poured into a preliminary agreement in the form of proof of confirmation of an order. Agreements made by the developer before the development has the power of proof. The strength of the evidence occurs if in the case of the agreement the parties do not deny part of the agreement. The responsibility of the developer in terms of the sale of the purchase of flats can be found from the beginning of the first publication of the flyer designation of the apartment unit by the seller. The application of PPJB flats occurred until after the transfer of flats from the developer of flats to consumers. If a loss occurs when the PPJB is still ongoing, then the brochure from the developer of the apartment can be used as a claim material for consumers if consumers feel aggrieved by the developer of flats. This loss is related to the facilities agreed on in the brochure brochure that are different from what is in the field. Protection for consumers of flats if a default occurs before the PPJB can be carried out through a deliberation agreement. However, if the consensus agreement does not reach the final decision agreed upon by both parties, then the consumer can use the claim line to the realm of the court or use a non-litigation route, namely the arbitration path to reach an agreement between the two parties.

Protection for consumers of the sharia unit if the purchase of goods with the order system is protected using PPJB. This is regulated in the Flats Law which regulates the sale and purchase of flats with an ordering system. Article 43 of the Housing Law is specified if the method of selling a flat before the apartment is completed can be done by making a PPJB which is carried out before a Notary. The preparation of the PPJB must also complete the certainty qualifications of several things such as; land ownership status, Building Construction Permit (IMB), availability of facilities, infrastructure and public utilities, at least $20 \%$ (twenty percent) of construction and part agreed upon between the developer company and the consumer at the time of sale and purchase of the apartment. The agreement relationship that occurs between companies selling flats with consumers buying flats begins with an agreement under the hand. The agreement under the hand was carried out between the parties namely the apartment developer company as the seller and the consumer buying the flat, then a SPPJB was signed, which was subsequently legalized by a Notary. ${ }^{22}$

Protection for consumers in the event of a loss in the sale and purchase of flats is also listed in Law Number 8 of 1999 concerning Consumer Protection, if the buyer feels disadvantaged then it can sue the seller in this case the apartment developer company to the agency that has the authority to settle problems between buyers and the seller in this case through the arbitration channel or through litigation, namely with the general court.

${ }^{22}$ Ramelan, E., et al. (2015). Op. Cit., p. 28 


\section{CONCLUSION}

The PPJB agreement is made in the process of purchasing flats with orders that have the power of proof as long as the parties to each other acknowledge the agreement and the contents of the agreement and there is no denial between the parties. PPJB agreements that are carried out when selling and purchasing apartment units with an order system, if used as evidence, then in the proof (validation) in the court it requires supporting other evidence such as witnesses to prove the truth of the evidence. PPJB is considered to have binding strength if it does not conflict with the laws and regulations.

Protection for consumers of flats in buying and selling through the order process is a protection that is carried out using the Sales and Purchase Agreement (PPJB). PPJB is a safeguarding effort for buyers in terms of the sale and purchase of a social unit with an order system. This effort is one of the preventive legal protection efforts. The consumer protection for buyers of flats with this ordering system is regulated by the requirements in the Flats Law.

\section{REFERENCE}

Adawiyah, P. P., \& Rahman, T. (2017). Analisis Yuridis Putusan PN. Surabaya Nomor: 869/ Pdt.G/2013/PN.SBY (Studi Kasus Ketidakpastian Tenggang Waktu PPJB ke AJB). Novum: Jurnal Hukum, Universitas Negeri Surabaya, 2(2).

Anggreni, L. D. M. (2016). Pembatalan Perjanjian secara Sepihak oleh Konsumen kepada PT. Bali Dewata Mas sebagai Pengembang Perumahan. (Sarjana Skripsi), Universitas Udayana, Denpasar.

Dewi, A. A. I. A. A. (2016). Kewenangan Pemerintah dalam Pengendalian Penduduk Pendatang dengan Melibatkan Desa Pakraman. Jurnal Magister Hukum Udayana (Udayana Master Law Journal), Universitas Udayana, 5(4), 871 - 894.

Fitriyani, D. N. (2014). Perlindungan Hukum bagi Pembeli dalam Jual Beli Satuan Rumah Susun dengan Sistem Pemesanan (Studi Kasus Putusan Pengadilan Negeri Jakarta Selatan Nomor 286/Pdt.G/2012/Jkt-Sel). (Magister Tesis), Universitas Gadjah Mada, Yogyakarta.

Hastuty, R. Y., Winarno, B., \& Istislam. (2015). Perlindungan Hukum terhadap Konsumen dalam Jual Beli Rumah Susun Komersial yang Belum Dibangun. Kumpulan Jurnal Mahasiswa Fakultas Hukum, Universitas Brawijaya, 1 - 25.

Illona, \& Anggraini, A. M. T. (2018). Perlindungan Hukum Konsumen dalam hal Pelaku Usaha Pengembang Rumah Susun yang Sudah Dinyatakan Pailit (Studi terhadap Kemanggisan Residence). Jurnal Hukum Adigama, Universitas Tarumanagara, $1(1)$. 
Kusumohamidjojo, B. (2017). Perancangan dan Legalitas Kontrak. Jakarta: CV. Mandar Maju.

Nurwulan, P. (2015). Aspek Hukum Transaksi Jual Beli Rumah Susun/Apartemen di Daerah Istimewa Yogyakarta Kaitannya dengan Peran Notaris-PPAT. Jurnal Hukum lus Quia Iustum, Universitas Islam Indonesia Yogyakarta, 22(4), 674 - 697.

Putri, A. D. U. (2010). Tanggung Jawab Developer dalam Perjanjian Pengikatan Jual Beli (Studi pada Apartemen Bellagio the Residence Mega Kuningan). (Magister Tesis), Universitas Diponegoro, Semarang.

Ramelan, E., et al. (2015). Perlindungan Hukum bagi Konsumen Pembeli Satuan Rumah Susun/Strata Title/Apartemen. Yogyakarta: Aswaja Pressindo.

S., Salim H., \& Nurbani, E. S. (2016). Penerapan Teori Hukum pada Penelitian Tesis dan Disertasi. Jakarta: PT. Raja Grafindo Persada.

Saputri, I. S. (2015). Kekuatan Hukum Perjanjian Pengikatan Jual Beli (PPJB) Tanah Menurut Hukum Perdata. (Sarjana Skripsi), Universitas Lampung, Bandar Lampung.

Shidarta. (2006). Hukum Perlindungan Konsumen Indonesia. Jakarta: Grasindo.

Simamora, N. A., Kamello, T., Sembiring, R., \& Leviza, J. (2015). Asas Itikad Baik dalam Perjanjian Pendahuluan (Voor Overeenkomst) pada Perjanjian Pengikatan Jual Beli Rumah (Studi Putusan Pengadilan Negeri Simalungun No 37/PDT/PLW/2012/ SIM). USU Law Journal, Universitas Sumatera Utara, 3(3), 84 - 96.

Triyanto, T., \& Adjie, H. (2018). Perlindungan Hukum terhadap Konsumen atas Perjanjian Pendahuluan dalam Jual Beli atas Satuan Rumah Susun yang Dipasarkan dengan Cara Pre Project Selling. Res Judicata, Universitas Muhammadiyah Pontianak, 1(1), $57-69$.

Widjaja, H., \& Tanawijaya, H. (2018). Analisis Perbuatan Melawan Hukum dalam Akta Perjanjian Pengikatan Jual Beli (PPJB) Tanah antara Koko Purnomo Santoso dengan PT. Intan Plaza Adika (Studi Kasus: Putusan Mahkamah Agung Nomor 17/K/Pdt/2016). Jurnal Hukum Adigama, Universitas Tarumanagara, 1(1).

Yudhantaka, L. (2017). Keabsahan Kontrak Jual Beli Rumah Susun dengan Sistem Pre Project Selling. Yuridika, Universitas Airlangga, 32(1), 84 - 104. 